\title{
Leaf anatomy changes related to physiological adaptations to flooding in Amazonian tree species
}

\author{
Ana Herrera ${ }^{1, *}$, Marcia Escala ${ }^{1}$ and Elizabeth Rengifo ${ }^{2}$. \\ ${ }^{1}$ Centro de Botánica Tropical, Instituto de Biología Experimental, Facultad de Ciencias, Universidad Central de \\ Venezuela, Caracas, Venezuela. \\ ${ }^{2}$ Centro de Ecología, Instituto Venezolano de Investigaciones Científicas, Altos de Pipe, Venezuela.
}

*Corresponding author: ana.herrera@ciens.ucv.ve. Tel. +58 212 7510111; fax: +58 2127535897

Received: 09 October 2009; Accepted: 31 January 2010.

\begin{abstract}
In trees of the seasonally flooded forest of the Mapire River in Venezuela, early flooding induces a reversible diminution in leaf conductance and photosynthetic rate. With the aim of finding an anatomical explanation for the observed responses of leaf gas exchange, the characteristics of emerged leaves developed under drainage or after three months of flooding were examined in the tree species Acosmium nitens, Campsiandra laurifolia, Duroia fusifera, Eschweilera tenuifolia, Pouteria orinocoensis and Symmeria paniculata and in leaves developed only under flooding in Inga spuria and Tachigali davidsei. Anatomy was remarkably similar among species and families and consisted of a bi-layered palisade parenchyma, a 5-6-cell-thick spongy parenchyma and large whole-leaf thickness. Anatomy also resembled that of xerophytes or evergreen species by possessing thick cuticles, large epidermal cells, thickened anticlinal epidermal cell walls and an abundance of sclerenchyma. Leaves of flooded v. un-flooded trees were not qualitatively different. Specific leaf area resembled values of deciduous species in tropical dry forests. No quantitative differences were found between leaves developed in un-flooded and flooded trees, with the exception of a reduction in whole-leaf thickness of $E$. tenuifolia, P. orinocoensis and S. paniculata and a change in the contribution of palisade parenchyma to leaf thickness in E. tenuifolia. Both stomatal size and density in these exclusively hypostomatous species remained unaffected by flooding. A decrease under flooding in whole-leaf thickness may have resulted in an increase in mesophyll conductance and therefore photosynthetic rate.
\end{abstract}

Key words: flooding, palisade, parenchyma, sclerenchyma, spongy, stomata, tropical trees

\section{RESUMO}

Anatomia foliar nas árvores de uma floresta estacionalmente inundada na Venezuela. Nas árvores da floresta sazonalmente inundada do rio Mapire em Venezuela, a inundação cedo induz uma diminuição reversível na condutância foliar e na taxa fotossintética. Com 0 objetivo de encontrar uma explanação anatômica para as respostas observadas na trocas gasosas nas folhas, as características das folhas emersas desenvolvidas sob a drenagem ou após três meses de inundação foram examinadas nas espécies nas espécies arbóreas Acosmium nitens, Campsiandra laurifolia, Duroia fusifera, Eschweilera tenuifolia Pouteria orinocoensis e Symmeria paniculata, e nas folhas desenvolvidas somente sob inundação de Inga spuria e Tachigali davidsei. A anatomia foi notavelmente similar entre as espécies e as famílias e consistiu em um parênquima paliçádico bi-celular, um parênquima lacunoso de 5-6 células e grande espessura da folha inteira. A anatomia assemelhou-se também àquele das xerófitas ou das espécies sempre-verdes possuindo cutículas grossas, células epidérmicas grandes, paredes anticlinais das epidermes engrossadas e uma abundância de esclerênquima. Folhas das árvores inundadas v. não inundadas não eram qualitativamente diferentes. A área 
foliar específica assemelhou-se a valores de espécies decíduas em florestas secas tropicais. Nenhuma diferença quantitativa foi encontrada entre as folhas desenvolvidas em árvores não inundadas e inundadas, à exceção de uma redução na espessura da folha inteira do $E$. tenuifolia, P. orinocoensis e $S$. paniculata e uma mudança na contribuição do parênquima paliçádico a espessura foliar em E. tenuifolia. 0 tamanho e a densidade estomáticos nestas espécies exclusivamente hipostomáticas permanesceram não afetados pela inundação. Uma diminuição sob inundação na espessura foliar pode estar relacionado ao aumento da condutância mesofilar e conseqüentemente da taxa fotossintética.

Palavras-chave: inundação, paliçada, parênquima, esclerênquima, lacunoso, estômatos, árvores tropicais

\section{INTRODUCTION}

In the seasonally flooded forest of the Mapire River (Venezuela), an acidic black-water flood lake (igapó) forms during the rainy season due to the increase in volume of the Mapire together with its damming by the Orinoco (VegasVilarrúbia and Herrera, 1993). The flood cycle is very regular, rising-waters occurring in May, full flood in July-August, falling-waters in September, and drainage in November-April, with a dry season that may impose some degree of water deficit in trees far removed from the river bed (Fernández et al., 1999; Herrera et al., 2008a).

All the arboreal species in this forest are evergreen; some species keep their submerged leaves for part or all of the flooded period, whereas others shed them within a few days of submergence. Leaf size does not change with flooding. Emerged leaves suffer a decrease in stomatal conductance and photosynthetic rate after approximately one month of flooding which is reverted at maximum flood, roughly two months later (Rengifo etal., 2005; Herrera etal., 2008a). When photosynthetic rate of several species decreased at rising-waters, maximum quantum yield of photosystem II also decreased, suggesting that part of the decrease in photosynthetic rate was due to impairment of photosynthetic capacity (Rengifo et al., 2005), which could well be related to leaf anatomical changes.

In trees of Campsiandra laurifolia and Symmeria paniculata flooding also reduced the slope of the linear portion of photosynthetic response curves to intercellular $\mathrm{CO}_{2}$ concentration and total soluble protein; relative stomatal limitation of photosynthesis was on average half the highest and relative non-stomatal limitation increased from the dry season to full flood (Herrera et al., 2008a). Under full flood, leaf gas exchange rates and total soluble protein regained high values, as did xylem sap flow velocity in $C$. laurifolia (Herrera et al., 2008b). Physiological responses to flooding in this species as well as in $S$. paniculata may be related, rather than to changes in leaf characteristics, to an increase in root water absorption due to the development of adventitious roots (Herrera et al., 2008b). Nevertheless, as leaf gas exchange is intimately linked to stomatal and mesophyll functioning, an influence of anatomical changes on stomatal conductance and photosynthetic rate must be considered.

The observed changes in photosynthetic capacity may also be the outcome of changes in total soluble protein and chlorophyll content (Herrera et al., 2008a) that in turn reflect anatomical variables, including number and/or size of parenchymatous cells. Photosynthetic rate is limited by mesophyll conductance, which is influenced by both leaf structure and the environment. In a study of several species of the sclerophyllous genus Banksia, a significant decrease of mesophyll conductance was associated with decreased specific leaf area, SLA (Hassiotou et al., 2009). Changes in SLA of flooded trees due to changes in whole-leaf thickness, number of cell layers and/ amount of sclerenchyma could modify mesophyll conductance and hence photosynthetic rate (Niinemets et al., 2009).

Stomatal density (SD) may also change as a response to one or more environmental factors (Tichá, 1982), including flooding, thus possibly affecting leaf gas exchange. Changes due to flooding in SD could also help explain the previously reported changes in stomatal conductance, since this is directly proportional to the fraction of leaf area occupied by stomata (Nobel, 1974).

Although there is an ample literature on the response to flooding of roots and stem of tropical trees (e.g. Pimenta et al., 1998 and references therein), fewer studies on leaf anatomy have been reported (e.g. Waldoff and Furch, 2002; Waldoff et al., 2002; Waldhoff 2003, Roth and Lindorf, 1991; Roças and Scarano, 2001). In order to elucidate whether previously observed seasonal changes in leaf gas exchange and biochemical components and the acclimation process are related to changes in leaf anatomical characteristics, we collected the youngest fully expanded leaves of nine tree species developed in drained or flooded soil in the field. 


\section{MATERIALS AND METHODS}

Plant material: Measurements were carried out in the forest of the Mapire river at $7^{\circ} 42^{\prime} \mathrm{N}, 64^{\circ} 46^{\prime} \mathrm{W}$ (Venezuela). The species studied are all important, evergreen components of the seasonally flooded forest of the Mapire River (Rosales, 1988) and comprised (common names in italics): Acosmium nitens (Vog.) Benth. (Papilionaceae, congrio), Campsiandra laurifolia Benth. (Mimosaceae, guamo), Duroia fusifera Hook. f. ex K. Schum. (Rubiaceae, carutilla), Eschweilera tenuifolia (Berg.) Miers. (Lecythidaceae, coco de mono), Inga spuria $\mathrm{H}$. and B. (Mimosaceae, guamo dulce), Pouteria orinocoensis (Aubr.) Penn. Ined. (Sapotaceae, cacho), Symmeria paniculata Benth. (Polygonaceae, chaparro) and Tachigali davidsei Zarucchi and Herend. (Caesalpiniaceae, guatero). Individuals may grow to $20 \mathrm{~m}$. Of these species, all but $A$. nitens and E. tenuifolia maintain viable submerged leaves. For our work, the youngest, fully expanded leaves exposed to full sunshine were collected during the rainy season from trees growing in drained soil or in the flood lake with a depth of over $3 \mathrm{~m}$.

Only emerged leaves were used for leaf anatomy, whereas both emerged and submerged leaves of five of the species were collected at different times of the flood cycle for the determination of SLA as a measure of sclerophylly.

Leaf anatomy: Transverse free-hand sections (two per one leaf of six differenttrees) of leaves preserved in commercial isopropanol were clarified with $10 \%$ commercial bleach, rinsed four times with distilled water, stained with toluidine blue and photographed with a Coolpix 7500 camera (Nikon, Japan) under a microscope (Leica Microsystems GmbH, Wetzlar, Germany) at x400 magnification. Measurements of whole leaf and tissue thickness were made on paper prints of the photographs; whole leaf thickness in $\mu \mathrm{m}$ was calculated using photographs of a calibrated stage micrometer, and relative tissue thickness measured with a ruler in order to avoid artifacts from dehydration shrinkage produced by conservation in isopropanol. Stomatal density was determined from nail-varnish impressions $(n=6)$ of both surfaces of leaf samples re-hydrated in warm water. Stomatal size (SS) was estimated as the product of the major and the minor axis of the stomatal ellipse multiplied by 0.78 (Tichá, 1982).

Specific leaf area: Leaf disks (one per one leaf of six different trees) were punched from the lamina, avoiding main veins, dried at $60^{\circ} \mathrm{C}$ for $72 \mathrm{~h}$ and weighed.
Statistics: Values reported are the means \pm one SE. Significance was assessed by one-way ANOVA at $p<0.05$ and the post-hoc Duncan's Multiple Range Test.

\section{RESULTS}

Emerged leaves of all seven species had similar crosssection anatomy (Figure 1). Leaves had thick upper and lower cuticles (UC and LC, respectively), very compact palisade parenchyma (PP) containing many chloroplasts and a looser spongy parenchyma (SP) with fewer chloroplasts. In sections of several species, a very dense staining was seen in PP cells which was affected by flooding, as in $E$. tenuifolia and $P$. orinocoensis. In leaves of $E$. tenuifolia, two PPs were observed, an adaxial thicker one and an abaxial thinner one. Anticlinal cell walls (CW) were thickened in both the upper (UE) and the lower (LE) epidermis; transcurrent vascular bundles (TVB) occurred in all species but $P$. orinocoensis. Sclerenchyma was abundant in these TVB and around the VB in $P$. orinocoensis, where brachy-sclereids (BS) traversing the SP were observed. No qualitative differences, such as appearance of aerenchyma or changes in the abundance of sclerenchyma, were evident between un-flooded and flooded trees.

In all of the species examined flooding decreased SLA, which was higher in young than in mature leaves and similar in mature emerged and submerged leaves (Figure 2). No significant differences were found between leaves developed in un-flooded and floodedc trees, with the exception of a reduction in whole-leaf thickness of E. tenuifolia, P. orinocoensis and S. paniculata and a change in the contribution of palisade parenchyma to leaf thickness in E. tenuifolia.

The proportions of each tissue that made up whole-leaf thickness (Figure 3) remained unaffected by flooding in all the species except for $E$. tenuifolia. Here, flooding was associated with thinner abaxial PP and SP and thus a thinner whole leaf, in a decrease not compensated for by a $15 \%$ increase in adaxial PP. Leaves in un-flooded trees of $S$. paniculata were twice as thick as those of $A$. nitens, $C$. laurifolia and $D$. fusifera. The PP was similar in thickness to SP in I. spuria and thicker in T. davidsei.

In all species examined under un-flooded and flooded conditions, the number of cells per parenchyma remained unchanged under flooding, at two for PP and four for SP; an exception was $E$. tenuifolia, in which the number of 
cells doubled under flooding in the adaxial PP (Table 1), in concordance with the increased PP thickness. All the species were hypostomatous and there were no statistically significant differences in either SS or SD between un-flooded and flooded trees (Table 1). In both I. spuria and T. davidsei the average number of cells per PP and SP was, respectively, 2 and 6 .

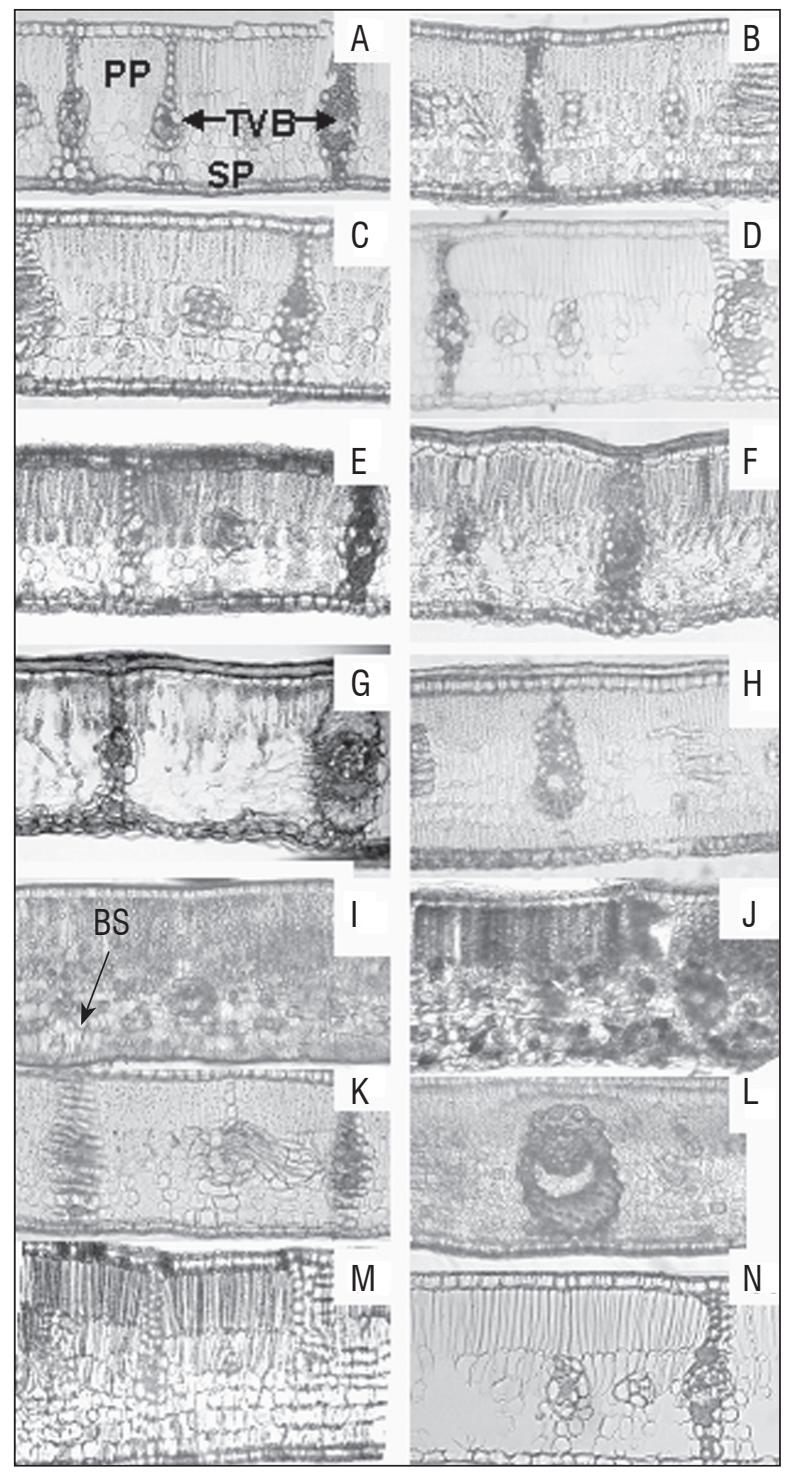

Figure 1. Cross-sections of leaves collected in the field from trees of: $A$, B, unflooded and flooded Acosmium nitens; C, D, unflooded and flooded Campsiandra laurifolia; E, F, unflooded and flooded Duroia fusifera; G, H, unflooded and flooded Eschweilera tenuifolia; I, J, unflooded and flooded Pouteria orinocoensis; K, L, unflooded and flooded Symmeria paniculata; M, flooded Tachigali davidsei, and N, flooded Inga spuria. BS, brachy-sclereids; PP, palisade parenchyma; SP, spongy parenchyma; TVB, transcurrent vascular bundle. Note the thickened anticlinal cell walls in the epidermes.

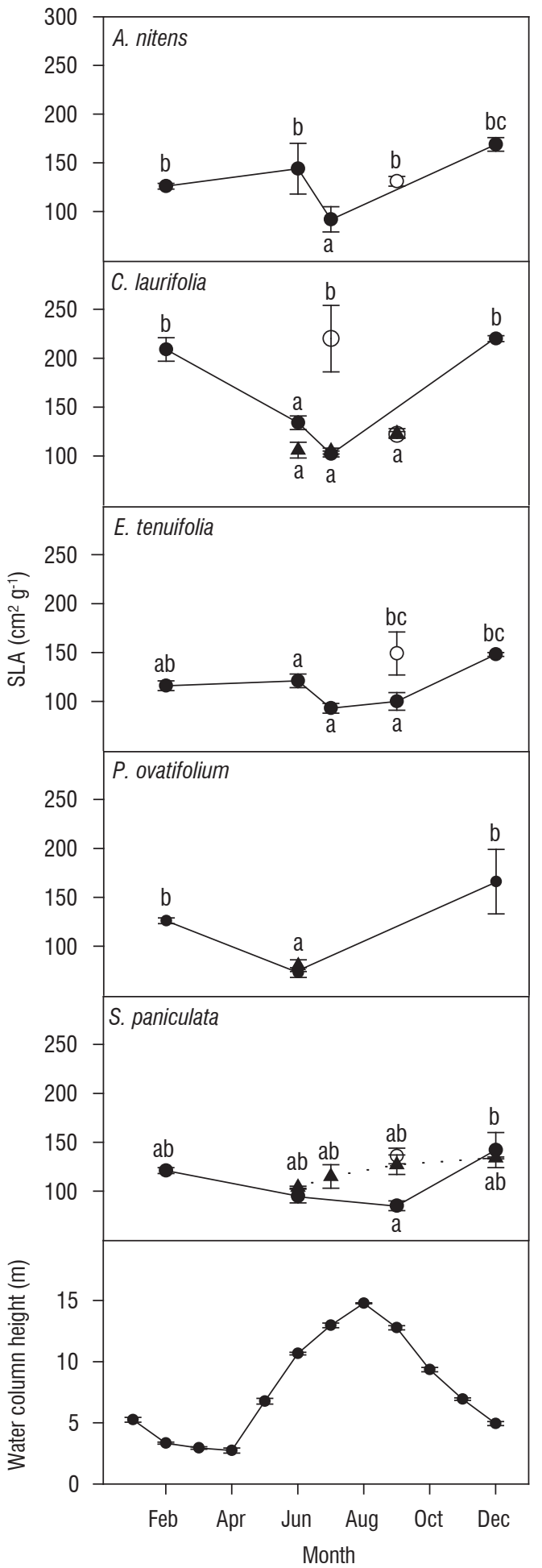

Figure 2. Seasonal changes in the species indicated in specific leaf area of mature emerged leaves (closed circles), young emerged leaves (open circles) and mature submerged leaves (triangles), and in water column height of the Mapire river. Values are mean $\pm S E(n=6)$. Different letters indicate significant differences among all leaf ages and season. 


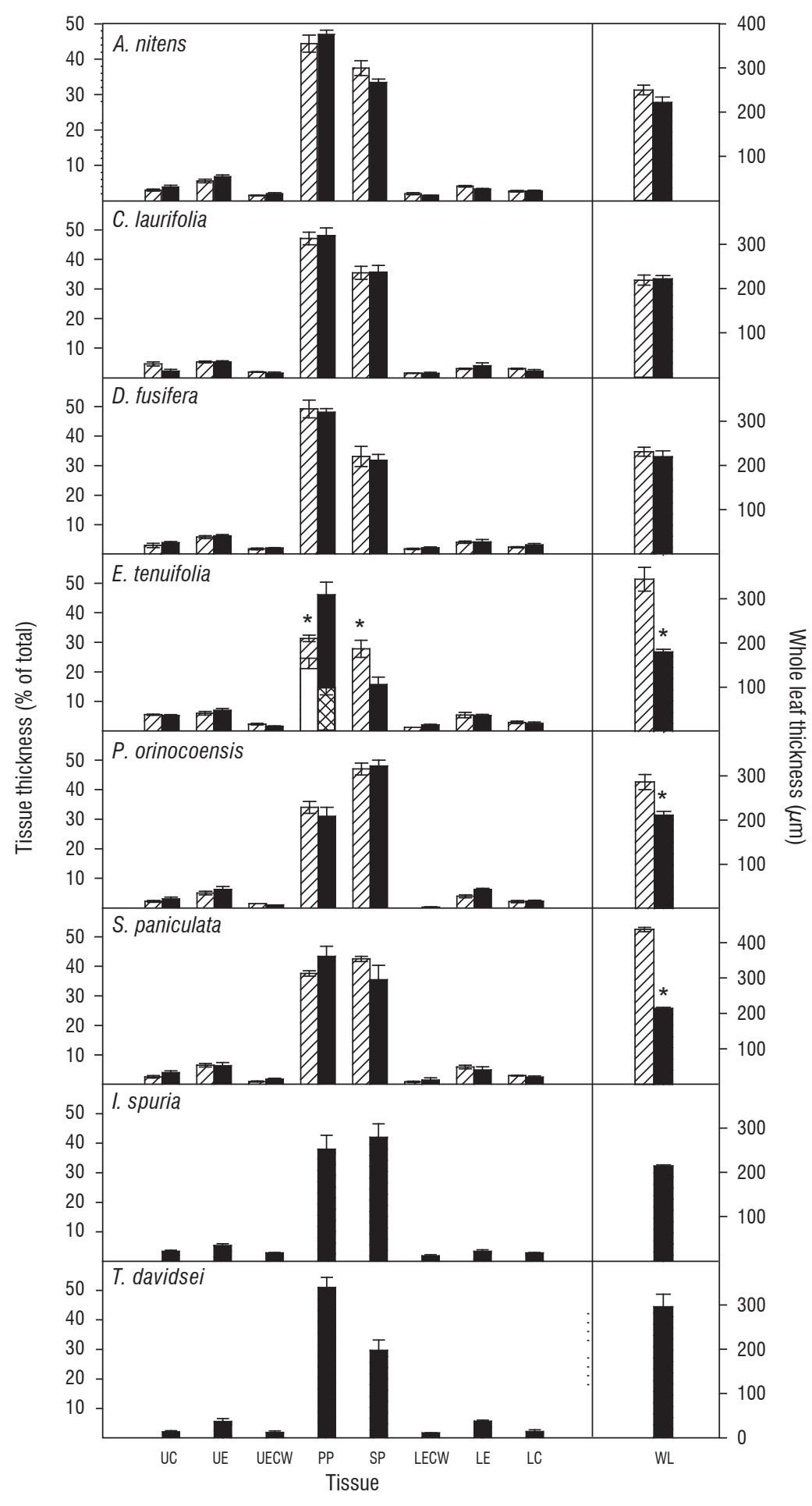

Figure 3. Relative tissue and whole-leaf thickness in leaves of the species indicated developed on drained (striped bars) or flooded (filled bars) trees. Open bar, abaxial PP in un-flooded E. tenuifolia; cross-hatched bar, abaxial PP in flooded E. tenuifolia. UC, upper cuticle; UE, upper epidermis; UECW, UE anticlinal cell wall; PP, palisade parenchyma; SP, spongy parenchyma; LECW, lower epidermis (LE) anticlinal cell wall; LC, lower cuticle; WL, whole leaf. Values are mean $\pm S E(n=12)$. An asterisk indicates a significant difference due to flooding $(p<0.05)$. 
Table 1. Changes with development under flooding of youngest fully expanded leaves in trees of the forest in the Mapire River in the number of cells in parenchymata, and abaxial stomatal size and density. Values are mean $\pm S E(n=12)$. Different letters next to values indicate significant differences $(p<0.05)$ due to flooding. $A D$, abaxial palisade parenchyma; $A B$, abaxial palisade parenchyma.

\begin{tabular}{|c|c|c|c|c|c|c|c|c|}
\hline \multirow{3}{*}{ Species } & \multicolumn{4}{|c|}{ Number of cells } & & & & \\
\hline & \multicolumn{2}{|c|}{ un-flooded } & \multicolumn{2}{|c|}{ flooded } & \multicolumn{2}{|c|}{ SS $\left(\mathrm{mm}^{2}\right)$} & \multicolumn{2}{|c|}{ SD $\left(s \mathrm{~mm}^{-2}\right)$} \\
\hline & palisade & spongy & palisade & spongy & un-flooded & flooded & un-flooded & flooded \\
\hline A. nitens & $2.3 \pm 0.2$ & $4.4 \pm 0.2$ & $2.2 \pm 0.2$ & $4.0 \pm 0.4$ & $200 \pm 15$ & $193 \pm 13$ & $320 \pm 25$ & $311 \pm 22$ \\
\hline C. laurifolia & $2.0 \pm 0.0$ & $4.4 \pm 0.4$ & $2.0 \pm 0.0$ & $4.0 \pm 0.2$ & $435 \pm 29$ & $543 \pm 59$ & $335 \pm 45$ & $352 \pm 47$ \\
\hline D. fusifera & $1.9 \pm 0.1$ & $4.3 \pm 0.4$ & $2.3 \pm 0.2$ & $4.5 \pm 0.3$ & $652 \pm 88$ & $700 \pm 20$ & $216 \pm 28$ & $291 \pm 61$ \\
\hline E. tenuifolia $A D$ & $1.0 \pm 0.0^{\mathrm{a}}$ & $1.6 \pm 0.2$ & $2.0 \pm 0.0^{b}$ & $1.7 \pm 0.2$ & $352 \pm 34$ & $401 \pm 25$ & $2309 \pm 282$ & $1617 \pm 144$ \\
\hline$A B$ & $1.8 \pm 0.5$ & & $1.2 \pm 0.2$ & & & & & \\
\hline P. orinocoensis & $1.0 \pm 0.0$ & $4.8 \pm 0.3$ & $1.0 \pm 0.0$ & $6.0 \pm 0.6$ & $802 \pm 82$ & $795 \pm 72$ & $166 \pm 7$ & $191 \pm 20$ \\
\hline S. paniculata & $2.0 \pm 0.0$ & $4.5 \pm 0.2$ & $1.7 \pm 0.3$ & $4.0 \pm 0.6$ & $216 \pm 14$ & $255 \pm 12$ & $341 \pm 53$ & $309 \pm 31$ \\
\hline
\end{tabular}

\section{DISCUSSION}

Leaf anatomy in eight flood-tolerant tree species of the forest of the Mapire igapó was remarkably similar despite belonging to different families. Leaf anatomy was generally typical of sun-adapted leaves, with thick multilayered SP and large whole-leaf thickness, as noted before in exposed leaves of several tree species of the humid forest of Venezuela (Lindorf, 1993; Roth and Lindorf,1991). Similarly, few qualitative differences were found when comparing leaves of flood-tolerant Pachira aquatica and flood-intolerant $P$. insignis, both showing structural features similar to those reported here (Roth and Lindorf, 1991). Other noteworthy anatomical features observed in the Mapire forest were: 1) the presence of $\mathrm{BS}$ in $P$. orinocoensis, suggested as a diagnostic character of the genus and Sapotaceae (Metcalfe and Chalk, 1957); 2) the heavy staining of PP cells observed in most of the species examined by us, which may be due to tannins, as suggested by Waldhoff et al. (2002) in the case of $S$. paniculata; 3 ) the presence of two PPs in E. tenuifolia, also reported by Waldhoff (2003), and 4) the presence of TBV.

Present in seven out of eight species in this study, TVB were previously reported in $A$. (Sweetia) nitens (Lindorf 1993) and in $95 \%$ of species constituting the upper canopy of a tropical rain forest, and their presence was interpreted as an adaptation to high radiation load and low $\mathrm{RH}$ in the highest forest level (Kenzo et al., 2007). The presence of TBV may result in non-homogenous distribution of stomatal aperture and the occurrence of isolated mesophyll patches (Beyschlag and Pfanz, 1990) which may bear some yet undisclosed physiological significance. The cells of the extensions in TVBs have been considered as possibly improving water status (Lindorf, 1993). In leaves of $A$. nitens, C. laurifolia, E. tenuifolia and $S$. paniculata, Herrera et al. (2008a) detected no stomatal patchiness with the method of Beyschlag and Pfanz (1990).

The most striking characteristic of these leaves was that their anatomy resembled more that of xerophytes or evergreen species than hygrophytes or mesophytes by having thick cuticles, large epidermal cells, thickened anticlinal epidermal cell walls and an abundance of sclerenchyma. A similar observation was made in species of Amazonian igapós (Waldhoff and Furch, 2002; Waldhoff, 2003). In addition, no distinctive anatomical characteristics were found in species that keep their submerged leaves in contrast to those that do not, as also noted by Waldhoff and Furch (2002) and Waldhoff (2003).

The SLA of species in the Mapire igapó was on average twice-and-a-half as high as in 11 species growing in a bana, a very nutrient-poor ecosystem in the Amazonas region (Sobrado and Medina, 1980), or as in five evergreen species of a dry tropical forest (Marín and Medina, 1981). Species of the bana have scleromorphic leaves that apparently evolved in response to oligotrophic sandy soils and widely fluctuating water table. These leaves have several anatomical features in common with xeromorphic species, including greater leaf and cuticle thickness, and a high incidence of sclerenchyma (Sobrado and Medina, 1980). Values of SLA in the Mapire 
forest were closer to those of deciduous species in the tropical dry forest than to bana species, suggesting that the Mapire ecosystem is not as nutrient-poor as the bana and this favours the production of less sclerophyllous leaves.

The scleromorphic characteristics of flooded trees in the Mapire igapó may reflect adaptations to drought and/or nutrient deficiency, as previously suggested for Amazonian species (Walhoff, 2003). Of the species we examined, only $A$. nitens and $C$. laurifolia are exposed to water deficit during the dry season because they grow along the complete savannariver water gradient. No qualitative differences in leaf anatomy of these two species were found in either wet or dry season or position along the savanna-river gradient (results not shown); therefore, we suggest that the observed scleromorphism is more related to nutrient deficiency. Nevertheless, in an Amazonian várzea, a white-water, nutrient-rich flooded ecosystem, the same structural characteristics found in the Amazonian igapó have been reported (Waldhoff and Furch, 2002; Waldhoff, 2003), leaving room for speculation on the role of nutrient deficiency in the occurrence of sclerophylly.

No quantitative differences between leaves developed in un-flooded and flooded trees were found, with the exception of a reduction in whole-leaf thickness of $E$. tenuifolia, $P$. orinocoensis and $S$. paniculata and a change in relative thickness of parenchymata in E. tenuifolia. These results contrast with observations done on Alchornea triplinervia (Roças and Scarano, 2001), where leaves and leaf parenchymata of plants growing in the field under un-flooded or flooded conditions were twice as thick in a primary compared to a secondary swamp forest or a montane forest. The number of cells per parenchyma also varied, again denoting a high plasticity in their environmental response to flooding.

In trees of the Mapire igapó the acclimation to flooding of leaf gas exchange may involve an increase in mesophyll conductance to $\mathrm{CO}_{2}$ (Herrera et al., 2008a). A decrease under flooding in whole-leaf thickness without any obvious reduction in the number of chloroplasts in $E$. tenuifolia, $P$. orinocoensis and $S$. paniculata may have increased mesophyll conductance. The question arises whether the thinner leaves of these species under flooding were fully expanded. The reported reversal during acclimation of photosynthetic rates in these leaves to values in drained trees (Rengifo et al., 2005; Herrera et al., 2008a) indicates that they were mature leaves. Since flooding decreased SLA in five of the species, it may be that per unit area thinner leaves had higher dry mass that could be represented by increased sclerenchyma, but our observations thus far do not support this conclusion. Rather, dry mass may have been due to increased total soluble protein and chlorophyll content, as shown by Herrera et al. (2008a).

In the present research, SD was unaffected by flooding. This is in contrast to previous reports that in $C$. laurifolia, $P$. ovatifolium and $S$. paniculata SD differed on average $26 \%$ between submerged leaves formed prior to flooding and emerged leaves that developed during flooding. However, the direction of change was not the same in each species (Fernández et al. 1999). The inconsistency between these data and ours could be due to the fact that our samples had been preserved in isopropanol, whereas their varnish impressions were done on fresh leaves. In tropical xerophytes, stomatal conductance did not appear to be governed by SD, SS, or proportion of leaf area occupied by stomata (Herrera and Cuberos, 1990). Therefore, we assume that possible changes with flooding in SD had a negligible impact on leaf conductance and consequently photosynthetic acclimation to flooding.

Stomata were as large as or larger than in some tropical xerophytes, where size ranged from 162 to $434 \mu \mathrm{m}^{2}$ (Herrera and Cuberos, 1990). Stomatal densities as high as in E. tenuifolia and ten times higher than in the other species examined were previously reported for the igapó species Mouriri guianensis (Waldoff, (2003). This species shares with E. tenuifolia the characteristic of having its stomata sunken in cuticular folds (Waldhoff and Furch, 2002).

Other qualitative morpho-anatomical responses to flooding are known. These include adventitious root formation in C. laurifolia and S. paniculata, and hypertrophied lenticels in the submerged stems of the latter species. Other likely anatomical responses of flooded trees include the formation of root or stem aerenchyma, which may help improve root aeration (Kozlowski, 1984).

We conclude that leaf anatomy does not help explain the photosynthetic acclimation to flooding in trees of the Mapire river igapó. Possible exceptions are E. tenuifolia, P. orinocoensis and $S$. paniculata, where a reduction in leaf and/or parenchymata thickness could increase mesophyll conductance and result in an increase in photosynthetic rate.

Acknowledgements: We appreciate the invaluable help in the field of J.L. Vallés. Ángel Fernández identified taxonomic 
samples of $D$. fusifera and $I$. spuria. Funds were given by Consejo de Desarrollo Científico y Humanístico, Venezuela (Grant 03.33.5415.2007).

\section{REFERENCES}

Beyschlag W, Pfanz H. 1990. A fast method to detect the occurrence of nonhomogenous distribution of stomatal aperture in heterobaric plant leaves. Experiments with Arbutus unedo L. during the diurnal course. Oecologia 82:52-55.

Fernández MD, Pieters A, Donoso C, Herrera C, Tezara W, Rengifo E, Herrera A. 1999. Seasonal changes in photosynthesis of trees in the flooded forest of Mapire river. Tree Physiol. 19:79-85.

Hassiotou F, Ludwig M, Renton M, Veneklaas EJ, Evans JR. 2009. Influence of leaf dry mass per area, $\mathrm{CO}_{2}$, and irradiance on mesophyll conductance in sclerophylls. J. Exp. Bot. 60:2303-2314.

Herrera A, Cuberos M. 1990. Stomatal size, density and conductance in leaves of some xerophytes from a thorn scrub in Venezuela differing in carbon fixation pathway. Ecotrópicos 3:67-76.

Herrera A, Tezara W, Marín 0, Rengifo E. 2008a. Stomatal and non-stomatal limitations of photosynthesis in trees of a tropical seasonally flooded forest. Physiol. Plantar. 134:41-48.

Herrera A, Tezara W, Rengifo E, Flores S, 2008b. Changes with seasonal flooding in sap flow of the tropical flood-tolerant tree species, Campsiandra laurifolia. Trees 22:551-558.

Kozlowski TT. 1984. Plant responses to flooding of soil. BioScience 34:162167.

Kenzo T, Ichie T, Watanabe Y, Hiromi T. 2007. Ecological distribution of homobaric and heterobaric leaves in trees of Malaysian lowland tropical rainforest. Amer. J. Bot. 94:764-775.

Lindorf H. 1993. Blattstruktur von Pflanzen aus einem feuchten Tropenwald in Venezuela. Bot. Jahrb. Syst. 115:46-51.

Marín D, Medina E. 1981. Duración foliar, contenido de nutrientes y esclerofilia en árboles de un bosque muy seco tropical. Acta Cient. Venez. 32:508-514.
Metcalfe C, Chalk L. 1957. Anatomy of the Dicotyledons, pp 872-873. Oxford Clarendon Press.

Niinemets Ü, Wright IJ, Evans JR. 2009. Leaf mesophyll diffusion conductance in 35 Australian sclerophylls covering a broad range of foliage structural and physiological variation. J. Exp. Bot. 60:2433 - 2449.

Nobel PS. 1974. Biophysical Plant Physiology. W.H. Freeman and Company, San Francisco, pp. 306-310.

Pimenta JA, Bianchini E, Medri ME. 1998. Adaptations to flooding by tropical trees: morphological and anatomical modifications. Oecol. Brasil. 6:157-76.

Rengifo E, Tezara W, Herrera A. 2005. Water relations, chlorophyll a fluorescence and carbohydrate contents in trees of a tropical forest in response to flood. Photosynthetica 43:203-210.

Roças G, Scarano FR. 2001. Leaf anatomical variation in Alchornea triplinervia (Spreng) Müll. Arg. (Euphorbiaceae) under distinct light and soil water regimes. Bot. J. Linn. Soc. 136:231-238.

Rosales J. 1988. Análisis florístico-estructural y algunas relaciones ecológicas en un bosque inundable en la boca del río Mapire, Edo. Anzoátegui. M. Sc. Thesis, IVIC. Venezuela.

Roth I, Lindorf H, 1991. Leaf structure of species of Pachira indigenous of Venezuela from different habitats. Bot. Jahrb. Syst. 113:203-219.

Sobrado MA, Medina E. 1980. General morphology, anatomical structure, and nutrient content of sclerophyllous leaves of the "bana" vegetation of Amazonas. Oecologia 45:341-345.

Tichá I. 1982. Photosynthetic characteristics during ontogenesis of leaves. 7. Stomatal density and sizes. Photosynthetica 16:375-471.

Vegas-Vilarrúbia T, Herrera R. 1993. Seasonal alternation of lentic/lotic conditions in the Mapire system, a tropical floodplain lake in Venezuela. Hydrobiol. 262:43-55

Waldhoff D, Furch B, Junk W. 2002. Fluorescence parameters, chlorophyll concentration, and anatomical features as indicators for flood adaptation of an abundant tree species in Central Amazonia: Symmeria paniculata. Environ. Exp. Bot. 48:225-235.

Waldhoff D, Furch B. 2002. Leaf morphology and anatomy in eleven tree species from Central Amazonian floodplains (Brazil). Amazoniana XVIl:79-94.

Waldhoff, D. 2003. Leaf structure in trees of Central Amazonian floodplain forests (Brazil). Amazoniana XVII:451-469. 